\title{
Utilization of Mangifera indica as Substrate to Bioremediate the Toxic Metals and Generate the Bioenergy through a Single- Chamber Microbial Fuel Cell
}

\author{
Sundas Bahar Yaqoob, ${ }^{1}$ Showkat Ahmad Bhawani, ${ }^{2}$ \\ and Rokhsana Mohammed Ismail Abdulrahman (iD) ${ }^{3}$ \\ ${ }^{1}$ Department of Zoology, Mirpur University of Science and Technology (MUST), 10250 Mirpur, Azad Jammu and \\ Kashmir, Pakistan \\ ${ }^{2}$ Faculty of Resource Science and Technology, University Malaysia Sarawak (UNIMAS), Kota Samarahan 94300, Malaysia \\ ${ }^{3}$ Chemistry Department, Faculty of Science, Aden University, Aden, Yemen
}

Correspondence should be addressed to Rokhsana Mohammed Ismail Abdulrahman; stc@aden-univ.net

Received 28 July 2021; Revised 19 August 2021; Accepted 27 August 2021; Published 15 September 2021

Academic Editor: Akil Ahmad

Copyright (C) 2021 Sundas Bahar Yaqoob et al. This is an open access article distributed under the Creative Commons Attribution License, which permits unrestricted use, distribution, and reproduction in any medium, provided the original work is properly cited.

\begin{abstract}
Microbial fuel cells (MFCs) are a sustainable approach for the remediation of metals and the simultaneous production of energy. This paper highlighted the usage of mango extract to produce electricity as an organic source for bacteria and reduce metal ions from wastewater. The observed results were $51 \mathrm{mV}$ in 15 days with $500 \Omega$ of external resistance. The whole operation was carried out at room temperature. The observed current and power density were $28.947 \mathrm{~mA} / \mathrm{m}^{2}$ and $0.972 \mathrm{~mW} / \mathrm{m}^{2}$, respectively. The internal resistance was $150 \Omega$, which is lower than external resistance. The remediation performance varied with the metal ions as follows: $\mathrm{Pb}$ (II) shows $75 \%$, Cd (II) shows $74.11 \%$, and $\mathrm{Cr}$ (III) shows $80.50 \%$. Finally, the detailed working mechanism of the present study, MFC challenges, and future research directions are covered in this paper.
\end{abstract}

\section{Introduction}

Among the bioelectrochemical approaches, the microbial fuel cell (MFC) has gained significant value in the current era. Due to the energy generation and simultaneously remediation of the toxic metals, which is the merit that makes the MFC more prominent. In MFC, the catalytic activity of microorganisms can transform the organic energy into electrical energy and at the same time convert the toxic pollutant to a less toxic form [1]. Concerning MFC, research has led to a growing number of papers and rapid growth in this field. The MFC approach is sustainable, secure, and efficient in bioelectricity production [2]. In the perspective of the present situation, two primary challenges are facing the modern world: wastewater issues and energy shortage. The wastewater from domestic areas and agricultural and industrial resources possess a major hazard for the green environment, where heavy metals, inorganic, and organic pollutants are present in large concentrations. Among all pollutants, the interest to discover a solution for the remediation of toxic metals from wastewater has increased. The most commonly detected metal ions in the wastewater are lead $(\mathrm{Pb})$, mercury $(\mathrm{Hg})$, nickel $(\mathrm{Ni})$, cadmium $(\mathrm{Cd})$, etc. Due to the metal ions' nonbiodegradability, high carcinogenicity, and toxicity, even at low concentrations, accumulation in the human body through food or water will have negative consequences on health $[3,4]$. Furthermore, batch sequence, photocatalysis, vertical treatment, and oxidation ditches are only a few of the accessible traditional wastewater treatment technologies. As a result, a contemporary method for wastewater treatment and energy generation must be investigated. According to the literature, presently, the bioelectrochemical approaches are the most suitable to bring them at a large scale to avoid several challenges [5-7]. 
Therefore, MFC has a lot of potential for remediation of toxic metals from wastewater while also producing electricity in the current day. The MFC operation is dependent on the bacterial catalytic activities. The bacterial species oxidized the provided organic substrate in MFC to generate the electrons and protons via the Krebs cycle process. A complete process of the Krebs cycle was well explained in previous studies $[8,9]$. Similar to other techniques, MFC has some issues which need careful attention to bring this approach at a commercial scale. In MFC, the organic substrate is the most important factor, which is responsible for bacterial activities in operation. Presently, a sustainable and long-lasting organic substrate with high performance is needed for this approach [10-12]. Usually, the carbohydratebased organic substrates are the most familiar in the MFC approach. According to Li et al. [13], the organic substrate is an important biological variable in MFC that impacts energy generation along with remediation efficiency. The substrate has an impact on the bacterial population's integral composition on anode biofilm. Several studies were reported on the utilization of different kinds of organic substrates in MFC configurations and types [8, 12, 14-16]. Therefore, according to previous literature, it was found that Mangifera indica (which is also commonly known as mango) has $15 \%$ simple sugar with other nutrients. The mango fruit has all nutrients that can promote bacterial growth as well as catalytic activities. In the present work, mango extract was used as an organic substrate in MFC operation to enhance energy generation as well as metal remediation. Presently, the study was carried out at a lab scale; therefore, highly toxic $\mathrm{Pb}$ (II), Cd (II), and Cr (III) are targeted to remediate from synthetic wastewater. Different electrochemical tests and biological characterizations were carried out to corroborate the present findings.

\section{Experimental Details}

2.1. Chemicals and Materials. Fresh mango was collected from the local market. Commercial graphite rods (FUDA 2B Lead, NY, USA), lead nitrate (R\&M Chemical), cadmium nitrate tetrahydrate (R\&M Chemical), and chromium (III) nitrate (R\&M Chemical) were used throughout the present study.

2.2. Preparation of Organic Substrate. In preparation of the organic substrate, $500 \mathrm{~g}$ fresh mangoes without peel and seed were washed and chopped gently. The chopped pieces of the mango were ground into a smooth puree using the simple blender machine. The ground pure mango liquid was purified to remove the fibrous pulp. The purified liquid known as mango extract is directly used as an organic substrate in MFC operation for 30 days. No water was used during the extraction process.

2.3. Preparation of Synthetic Wastewater for the Inoculation Source in MFC. Local wastewater was collected and supplemented with $50 \mathrm{ppm}$ of each metal ions ( $\mathrm{Pb}, \mathrm{Cd}$, and $\mathrm{Cr}$ ). In this work, the metal-supplemented wastewater was described as synthetic wastewater and then utilized as an inoculation source in MFC. Table 1 shows several physicochemical characteristics of local, untreated wastewater, and synthetic wastewater. Using $\mathrm{pH}$ paper and a thermometer, the $\mathrm{pH}$ and temperature were recorded.

2.4. MFC Reactor and Operation. A single-chamber MFC was utilized in this experiment. The MFC chamber height was $16.0 \mathrm{~cm}$ with a diameter of $13.0 \mathrm{~cm}$. The single-chamber MFC had a total volume of $1,000 \mathrm{~mL}$; however, it was inoculated with $800 \mathrm{~mL}$ of prepared synthetic wastewater. In MFC, the commercial graphite rods were vertically implanted, and the size of the graphite anode electrode was $15 \mathrm{~cm} \times 1 \mathrm{~cm}(h \times r)$, and the graphite rod as cathode electrode was $10 \mathrm{~cm} \times 1 \mathrm{~cm}(h \times r)$. The distance between the anode and the cathode electrode was $15 \mathrm{~cm}$. The external resistance was $500 \Omega$; both electrodes were linked to external resistance using the titanium wire. The $5 \mathrm{ml}$ organic substrate (mango extract) was added to the single-chamber MFC every day for 30 days. The MFC experiment was run for 30 days at a room temperature of 25 to $30^{\circ} \mathrm{C}$.

2.5. Analytical Measurements and Calculations. A digital multimeter (UNI-T UT33 $\mathrm{B}^{+}$, China) was used to measure the potential voltage between the anode and the cathode once every 24 hours. Voltage was converted into current using Ohm's law (Ampere). The following equations were used to determine the current density (CD), power density (PD), and internal resistance $(r)$ :

$$
\begin{aligned}
V & =\mathrm{IR}, \\
\mathrm{PD} & =\frac{V^{2}}{\mathrm{RA}}, \\
\mathrm{CD} & =\frac{I}{A}, \\
r & =\left[\frac{E-V}{V}\right] R .
\end{aligned}
$$

where $V$ represents voltage output, $A$ represents area, $I$ represents current, and $E$ represents electromotive force [8].

An open-circuit voltage (OCV) was used to measure the electromotive force. The internal resistance of MFC was calculated using the slope of the polarization curve and a variable resistance box ranging from 6,000 to $100 \Omega$.

\subsubsection{Cyclic Voltammetry and Specific Capacitance.} Using cyclic voltammetry (CV-Model BAS Epsilon Version 1.4, Germany), the redox processes on the electrode surface were investigated. On the $10^{\text {th }}, 20^{\text {th }}$, and $30^{\text {th }}$ days, the $\mathrm{CV}$ analysis was examined at a $10 \mathrm{mV} / \mathrm{s}$ scanning rate with a potential range of $+0.8 \mathrm{~V}$ to $-0.8 \mathrm{~V}$. The counter and working electrodes were platinum wire and graphite rod, respectively. While the $\mathrm{Ag} / \mathrm{AgCl}$ was used as the reference electrode. The reference electrode was used to determine the electrode potential. The specific capacitance, $C_{s}(\mathrm{~F} / \mathrm{g})$, is defined as the 
Table 1: Physicochemical characteristics of local untreated wastewater and synthetic wastewater.

\begin{tabular}{lcc}
\hline Parameters & Local without metal containing wastewater & Synthetic wastewater \\
\hline Color & Yellowish & Dim yellowish \\
$\mathrm{pH}$ & 6.97 & 6.65 \\
Temperature & $24 \pm 3^{\circ} \mathrm{C}$ & $24 \pm 3^{\circ} \mathrm{C}$ \\
Odor & Unpleasant smell & Unpleasant smell \\
$\mathrm{Pb}$ (II) & 0 & $50 \mathrm{ppm}$ \\
$\mathrm{Cd}$ (II) & 0 & $50 \mathrm{ppm}$ \\
$\mathrm{Cr}$ (III) & 0 & $50 \mathrm{ppm}$ \\
\hline
\end{tabular}

sum of both anode and cathode data per unit area of the cathode and anode area. The $C_{s}$ values were assessed using the $\mathrm{CV}$ curves information and using the following equation:

$$
C_{p}=\frac{A}{2 \mathrm{mk}\left(V_{2}-V_{1}\right)},
$$

where the $A=$ area of the $\mathrm{CV}$ curve, $k=$ scan rate in $\mathrm{mV} / \mathrm{s}$, and $\left(V_{2}-V_{1}\right)=$ is the voltage range.

2.6. Bioremediation Performance and Biofilm Studies. For the bioremediation performance, the concentration of metal ions was evaluated using an atomic absorption spectrometer (AAS; PerkinElmer AAnalyst 400, USA). Every 10 days, around $2 \mathrm{~mL}$ of synthetic wastewater was received from the MFC and was examined for the metal concentration. The following equation was applied to determine the percentage of bioremediation efficiency:

$$
\text { bioremediation efficiency } \%=\frac{M_{\text {initial }}-M_{\text {final }}}{M_{\text {initial }}} \times 100 \text {, }
$$

where the $M_{\text {initial }}=$ initial concentration of metal ions and $M_{\text {final }}=$ final concentration of metal ions. The surface morphology of the anode biofilm was performed by the scanning electron microscopy (ZEISS GeminiSEM 560, Germany).

\section{Results and Discussion}

3.1. Voltage Potential Trend, Polarization Studies, and Internal Resistance. Using mango extract as an inoculation source in MFC, the operation was effectively carried out for 30 days. The operation was maintained for 30 days to reach the maximum voltage production, as shown in Figure 1. On the $15^{\text {th }}$ day, the maximum achievable voltage was $51 \mathrm{mV}$ $(0.051 \mathrm{~mA})$. When the first cycle was completed, the voltage began to drop until it reached $27 \mathrm{mV}(0.027 \mathrm{~mA})$. It might be because certain bacterial species have completed their life cycle. In a single chamber of the MFC, there is a mixed culture. After some time, the voltage trend again started increasing and reached up to $32 \mathrm{mV}(0.032 \mathrm{~mA})$, although the value recorded in the first cycle was still high. After day 22 , which shows operating completeness, the voltage continually started decreasing. Under the open circuit, the measured voltage was $200 \mathrm{mV}$. Furthermore, Yaakop et al. [8] also followed the same trend to explain the voltage generation. They also stated that the maximum voltage

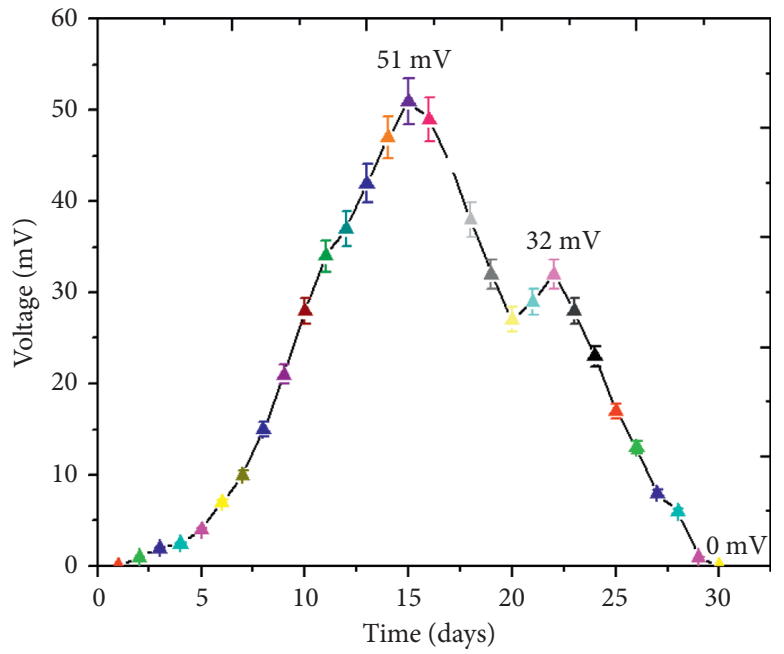

FIGURE 1: Voltage generation trend in the presence of mango extract as the substrate in MFC operation.

generation point is also referred to as the turning point of the metal ion into metal oxide form. This means that on days $15^{\text {th }}$ and $22^{\text {nd }}$, which indicated the conversion of the $\mathrm{Pb}(\mathrm{II})$, $\mathrm{Cd}$ (II), and Cr (III) ions into metal oxide form. The produced sludge on the completion of the operation is a metal oxide. It is already reported in the literature that MFC is the most efficient technique to recover the metal from wastewater.

In addition, a polarization study was carried out to examine the $\mathrm{CD}$, voltage, and PD connection by changing the external resistance. During continuous MFC operation, the $6,000 \Omega$ to $100 \Omega$ resistance were attached one by one. The observation indicated high external resistance due to the electric resistance and instability, indicating the transit of electrons was poor. Due to fast electron transfers, the low outer resistance demonstrated reduced stability in electrical mobility. For viable electrical change without ohmic resistance, both external/internal resistance of the MFC should be parallel. A range of external resistance was applied to locate the optimal fixed external resistance before the procedure. The voltage reduced from the open-circuit voltage and was subsequently recovered at a high external resistance. However, the cell design point was found at $500 \Omega$ through external resistance variations. The maximum $\mathrm{PD}$ and $\mathrm{CD}$ obtained, respectively, were $0.972 \mathrm{~mW} / \mathrm{m}^{2}$ and $28.947 \mathrm{~mA} /$ $\mathrm{m}^{2}$ as shown in Figure 2. The observed internal resistance was $150 \Omega$. The higher external resistance than $500 \Omega$ is also indicative of a reduction in electron transport. Therefore, the 


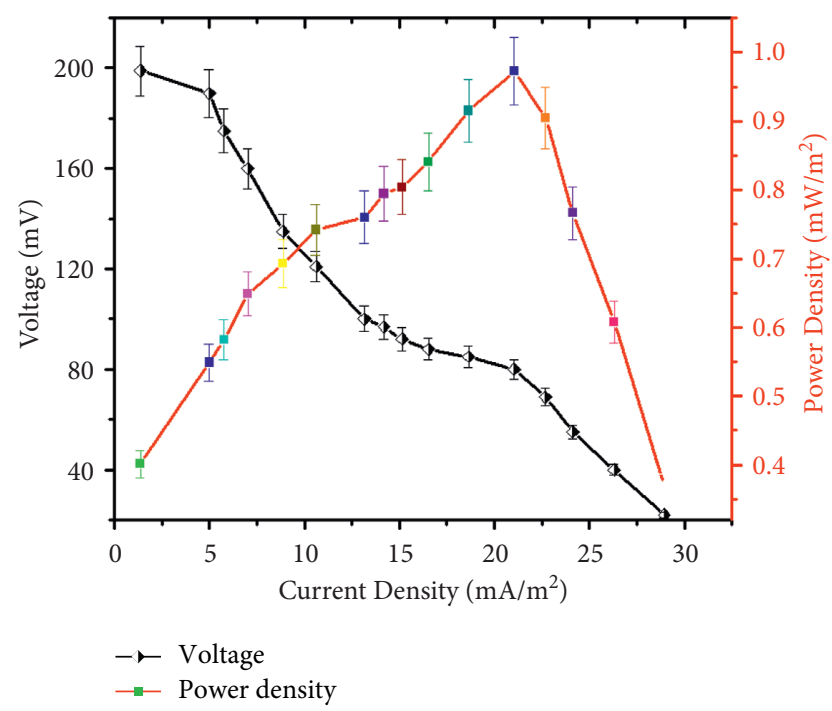

FIGURe 2: Polarization behavior of the MFC operation fed with mango extract.

external resistance of $500 \Omega$ in comparison to others may give the maximum energy output. The observation showed a maximum of $0.501 \mathrm{~mW} / \mathrm{m}^{2} \mathrm{PD}$ at $6,000 \Omega$ and a maximum of $0.367 \mathrm{~mW} / \mathrm{m}^{2} \mathrm{PD}$ at $100 \Omega$. It also implies that the resistance to electrical electronics has to be careful not to destabilize the electron resistivity. The internal resistance of the anode and cathode anode can be reduced by lowering the distance. Therefore, several studies have a preference to use single-chamber MFC as a substitute for double-chamber MFC $[6,17,18]$.

3.2. Operational Potential Studies via Cyclic Voltammetry and Specific Capacitance. Figure 3(a) shows the CV curves measured during the MFC process at different intervals to examine electrical mobility. The CV curves indicated the current at different times in the forward (FS) and reverse (RS) scans. On day 10, the FS was $0.000005 \mathrm{~mA}$; on day 20 , it was $0.0000075 \mathrm{~mA}$; and on day 30 , it was $0.000013 \mathrm{~mA}$, while on day 10 , the RS was $-0.000006 \mathrm{~mA}$; on day 20 , it was $-0.000008 \mathrm{~mA}$, and on day 30 , it was $-0.000008 \mathrm{~mA}$. On day 30 , FS and RS were seen maximum. It implies that the oxidation and reduction rates of the organic substrate were high and steadily increased and achieved an upper limit on the $30^{\text {th }}$ day. In general, during the operation, the CV demonstrated maximal oxidation and reduction rates.

Furthermore, CV curves are also investigated to derive the $C_{s}$ values. During the operation, the $C_{s}$ values revealed the development rate and stability of the biofilm. According to the CV information, it was seen the biofilm being generated steadily and with mango extract as an organic substrate showing good stability for 30 days. The $C_{s}$ low value usually implies that the formation of biofilm is ongoing or a less steady but progressive rise, showing a high level of biofilm stability on the anode. Figure 3(b) reveals the $C_{s}$ value of this investigation, which demonstrates the excellent biofilm performance. Several studies followed this trend to study the stability and growth of biofilm $[19,20]$.
3.3. Bioremediation of Metals. The MFC remediation of metal ions is a developing field nowadays. The newest area of research recently came with the concept of using the high carbohydrate-based organic substrate to generate power and reduce the concentration of metal ions. Metal remediation using MFC fed with mango extract has been performed in this work. Each metal concentration of $50 \mathrm{ppm}$ was selected since it was shown to be the most favorable in MFC in prior research. Li et al. [21] optimized various concentrations $\mathrm{Pb}$ (II), Cd (II), and Cr (III) (50 ppm, $100 \mathrm{ppm}$, and $200 \mathrm{ppm})$ and identified that the $50 \mathrm{ppm}$ as very effective remediation without a harmful effect on the bacterial population. Several additional investigations have found that there are no harmful consequences of a metal ion level of $50 \mathrm{ppm}$ on a laboratory scale [22-24]. In addition, numerous studies have previously shown that MFC is a successful way of reducing metal ion concentration [24-26]. In the present study, the remediation efficiency was $\mathrm{Pb}$ (II) $=75 \%$, whereas in 30 days, the remediation efficiency of Cd (II) and Cr (III) was $74.11 \%$ and $80.50 \%$, respectively. Based on the pattern observed, the concentration of metal ions decreased progressively. Primarily, it was not very high, but with time, it improved and attained maximum remedial efficiency. Due to the fresh and steady inoculation source, a high rate of metal removal was obtained. In comparison with previous studies, the present results are very interesting and unique. For instance, recently Umar et al. [27] achieved $60.33 \%=\mathrm{Pb}$ (II) and $65.51 \%=\mathrm{Cd}$ (II) remediation efficiencies within 40 days of benthic MFC operation using the sweet potato as organic substrate. Mango extract is a suitable organic substrate for the transfer of extracellular electrons by bacterial activities. Table 2 shows a comprehensive trend in the current investigation.

\subsection{Scanning Electron Microscopy Studies of Anode Biofilms.} On completion of MFC operation, an anode-biofilm analysis was conducted. The electrode was analyzed before and after the operation in the context of the SEM study. Figure 4 shows the SEM images of the anode without biofilm and anode with biofilm. The SEM image of the anode with biofilm shows dense bacterial species which indicates that no toxicity was experienced throughout the operation. The dense and clear growth of the bacterial species is equivalent to adequate bacterial activity by the supplied inoculation source. The organic substrate has a major influence on bacterial growth and stability throughout the MFC operation. Unique consequences have been obtained in this study. It is noted from the SEM observation that the morphology is almost similar on anode with biofilm electrode, that is, the tube/rod-like filament attachments are virtually similarly visible. Several investigations of the MFC field have shown the presence of conducting pili species with filamentous appendages/rodshaped morphology such as Klebsiella pneumoniae, Acinetobacter species, Escherichia species, Lysinibacillus species, Proteus species, and Bacillus species [8, 28].

3.5. MFC Mechanism of the Present Study. The MFC strategy is based mostly on bacterial species catalysis activities. Several well-familiar metal-reducing and exoelectrogenic 


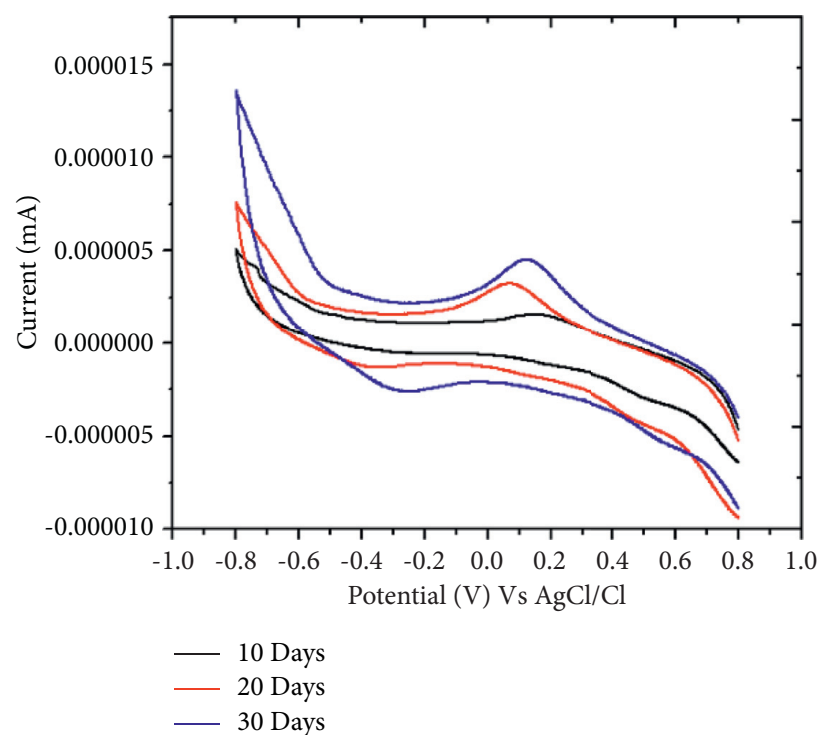

(a)

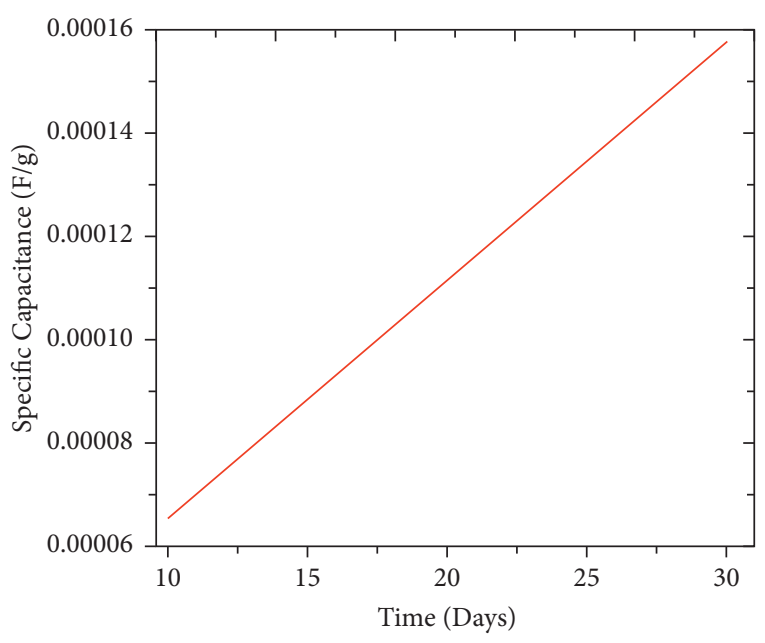

(b)

Figure 3: (a) CV curves at different time intervals. (b) $C_{s}$ values during the MFC operation.

TABLE 2: Bioremediation trend of the toxic metals via single-chamber MFC fed with mango extract as the organic substrate.

\begin{tabular}{|c|c|c|c|c|c|c|c|}
\hline $\begin{array}{l}\text { Target } \\
\text { pollutant }\end{array}$ & $\begin{array}{l}\text { Organic } \\
\text { substrate }\end{array}$ & $\begin{array}{c}\text { Inoculation } \\
\text { source in the } \\
\text { anode chamber }\end{array}$ & $\begin{array}{c}\text { Initial } \\
\text { concentration of } \\
\text { metal ions }(\mathrm{ppm})\end{array}$ & $\begin{array}{l}\text { Operational } \\
\text { time (days) }\end{array}$ & $\begin{array}{c}\text { Bioremediation } \\
\text { efficiency (\%) of } \mathrm{Pb} \\
\text { (II) }\end{array}$ & $\begin{array}{l}\text { Bioremediation } \\
\text { efficiency (\%) of } \\
\text { Cd (II) }\end{array}$ & $\begin{array}{c}\text { Bioremediation } \\
\text { efficiency (\%) of } \mathrm{Cr} \\
\text { (III) }\end{array}$ \\
\hline $\mathrm{Pb}$ (II) & \multirow{4}{*}{$\begin{array}{l}\text { Mango } \\
\text { extract }\end{array}$} & \multirow{4}{*}{$\begin{array}{c}\text { Synthetic } \\
\text { wastewater }\end{array}$} & \multirow{4}{*}{100} & 0 & 0.00 & 0.00 & 0.00 \\
\hline Cd (II) & & & & 10 & 30.10 & 29.00 & 34.90 \\
\hline \multirow{2}{*}{ Cr (III) } & & & & 20 & 57.50 & 61.10 & 64.20 \\
\hline & & & & 30 & 75.00 & 74.11 & 80.50 \\
\hline
\end{tabular}

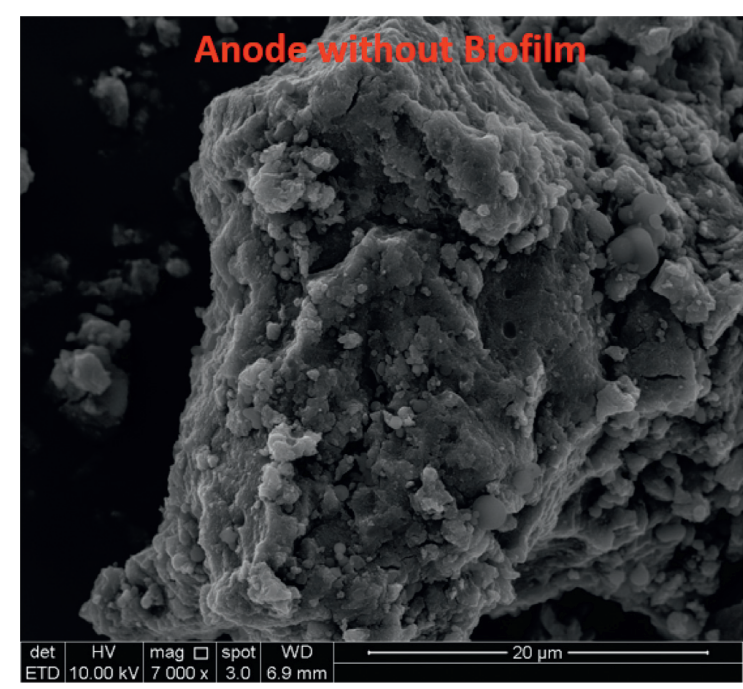

(a)

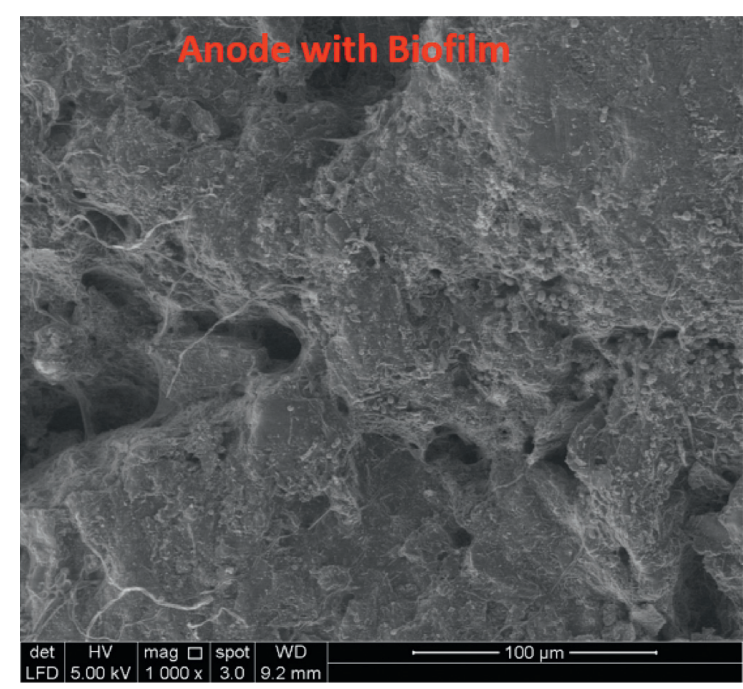

(b)

FIGURE 4: SEM images of (a) anode electrode without biofilms and (b) anode electrode with biofilms. 
bacteria were found in this investigation. The oxidation of organic substrate in MFC operation produces electrons and protons [29]. In this study, bacterial species initiate the oxidation of mango extract by converting it to simple sugar, which is then oxidized to create electrons and protons:

$$
\begin{aligned}
& \text { Anodic } \quad \text { reaction: } \\
& \text { extract } \longrightarrow \mathrm{C}_{6} \mathrm{H}_{12} \mathrm{O}_{6}+6 \mathrm{H}_{2} \mathrm{O} \longrightarrow 6 \mathrm{CO}_{2}+24 \mathrm{H}^{+}+24 \mathrm{e}^{-} \\
& \text {Cathodic reaction: } 24 \mathrm{H}^{+}+24 \mathrm{e}^{-}+6 \mathrm{O}_{2} \longrightarrow 12 \mathrm{H}_{2} \mathrm{O} \\
& \text { Overall } \\
& \mathrm{C}_{6} \mathrm{H}_{12} \mathrm{O}_{6}+6 \mathrm{O}_{2} \longrightarrow 6 \mathrm{CO}_{2}+6 \mathrm{H}_{2} \mathrm{O}+\text { electricity }
\end{aligned}
$$

From the anode, the generated electrons and protons are transported to the cathode. Protons may go from anode to cathode directly, but electrons must go through the outside circuit. There is also a stage of electron transmission from bacteria cells to the anode surface before electron transit towards the cathode. The anode biofilm is a set of bacterial exoelectrogens. Figure 5 depicts the most often reported process for electron transmission from bacterial species to anode electrodes. A few common electron transfer mechanisms are given as follows:

(i) Conductive pili-typed species are responsible for long-range electron transport. The conductive pili is a bacterial body component that is conductive, like a metal. This conductive component makes it simple to transmit electrons from one conductive anode to another. Geobacter sulfurreducens, Shewanella oneidensis, Pelotomaculum thermopropionicum, and other conductive pili-typed organisms are well known in MFC [3].

(ii) Short-range electron transport is a bacterial process in which oxidized shuttle and reduced shuttle molecules are used. Few bacterial species generate their electron shuttle molecules, which they then employ to transport electrons. The most frequent families are Desulfuromonadaceae and Geobacteraceae.

(iii) Redox-active proteins are also used to transport electrons. A typical method for transferring electrons to the anode's surface is G. sulfurreducens. $\mathrm{OmcB}, \mathrm{OmcT}$, OmcS, OmcZ, and OmcE are some of the most often reported redox-active proteins [30].

Furthermore, the results of biological tests and evidence from the literature showed that the current study employs a long-range electron transfer method via conductive pili. In earlier research, they found that bacterial species were also known as exoelectrogens and metal-reducing species. The soluble metal ions, on the other hand, are transformed into insoluble forms. Furthermore, the AAS findings only show the metal ion concentrations that have been eliminated. Metal ions are removed from MFC and transformed to oxide form, which appears as sludge. According to numerous publications, the removed metal ions are efficiently transformed to the oxide state, and the resultant sludge contains the oxide form of metals [24]. On the other hand, the metal biochemical process may be expressed as follows: (i) Conversion of $\mathrm{Pb}^{2+}$ into $\mathrm{Pb}_{(\mathrm{s})}$

$$
\begin{aligned}
& \mathrm{Pb}^{2+}+2 \mathrm{e}^{-} \longrightarrow \mathrm{Pb}_{(\mathrm{s})} \\
& 2 \mathrm{~Pb}^{2+}+2 \mathrm{H}_{2} \mathrm{O} \longrightarrow 2 \mathrm{PbO}+4 \mathrm{H}^{+} \\
& \mathrm{PbO}+2 \mathrm{e}^{-}+2 \mathrm{H}^{+} \longrightarrow \mathrm{Pb}_{(\mathrm{s})}+\mathrm{H}_{2} \mathrm{O}
\end{aligned}
$$

(ii) Conversion of $\mathrm{Cd}^{2+}$ into $\mathrm{Cd}_{(\mathrm{s})}$

$$
\begin{aligned}
& \mathrm{Cd}^{2+}+2 \mathrm{e}^{-} \longrightarrow \mathrm{Cd}_{(\mathrm{s})} \\
& 2 \mathrm{Cd}^{2+}+2 \mathrm{H}_{2} \mathrm{O} \longrightarrow 2 \mathrm{CdO}+4 \mathrm{H}^{+} \\
& \mathrm{CdO}+2 \mathrm{e}^{-}+2 \mathrm{H}^{+} \longrightarrow \mathrm{Cd}_{(\mathrm{s})}+\mathrm{H}_{2} \mathrm{O}
\end{aligned}
$$

(iii) Conversion of $\mathrm{Cr}^{3+}$ into $\mathrm{Cr}_{(\mathrm{s})}$

$$
\begin{aligned}
& \mathrm{Cr}^{3+}+3 \mathrm{e}^{-} \longrightarrow \mathrm{Cr}_{(\mathrm{s})} \\
& 2 \mathrm{Cr}^{3+}+3 \mathrm{H}_{2} \mathrm{O} \longrightarrow \mathrm{Cr}_{2} \mathrm{O}_{3}+6 \mathrm{H}^{+} \\
& \mathrm{Cr}_{2} \mathrm{O}_{3}+6 \mathrm{e}^{-}+6 \mathrm{H}^{+} \longrightarrow 2 \mathrm{Cr}_{(\mathrm{s})}+3 \mathrm{H}_{2} \mathrm{O}
\end{aligned}
$$

\section{Challenges and Future Research Recommendations}

MFC has provided a fresh research path and is controlled, eco-friendly, and ecologically stable for energy production as well as wastewater bioremediation. MFC is now gaining a lot of attention, and they may be used in a variety of applications such as wastewater bioremediation (removal of heavy metals, organic, and inorganic compounds), biological oxygen demand sensors, and gastrobots (food digester tools). Furthermore, benthic and sedimentary MFC are the two kinds of MFC. Both types of MFC provide a plethora of options for empowering sea-bred gadgets, monitoring and tracking systems, and so forth. As a result, the production of highly conductive electrodes and their modification with various metals or conducting polymers make MFCs more widespread and important in terms of electronic applications. MFC is a revolutionary technology that produces clean, safe, and sustainable energy for humans while also preserving the earth's clean environment. Furthermore, MFC is a new subject in science; it will take a lot of effort and time to make them commercially viable. Presently, still, the instability of organic substrate and electrode material is one of the emerging issues in MFC [31]. Although the present study delivered good results, it cannot survive more than 30 days. The MFC commercial-scale practice needs a long-term stable organic substrate. Recently, oil palm trunk sap was used in MFC as substrate, and it showed around 90 days stability. The high stability with high content of carbohydrates basis organic substrate is highly needed to cover this issue to bring the MFC at a pilot scale. Another common issue found in MFC is the utilization of electrode material. The energy was still not sufficient through MFC due to electrode material. The electrode material particularly anode should transport the electrons more effectively and provided a biocompatible environment for bacteria to produce a biofilm around the anode surface. Recently, the waste-derived electrode material is the most promising talk due to its effective cost and performance $[2,32]$. The conversion of biomass into electrode form such as biomass-derived anode electrodes is well studied previously. Sincere efforts are needed in this field at present. 


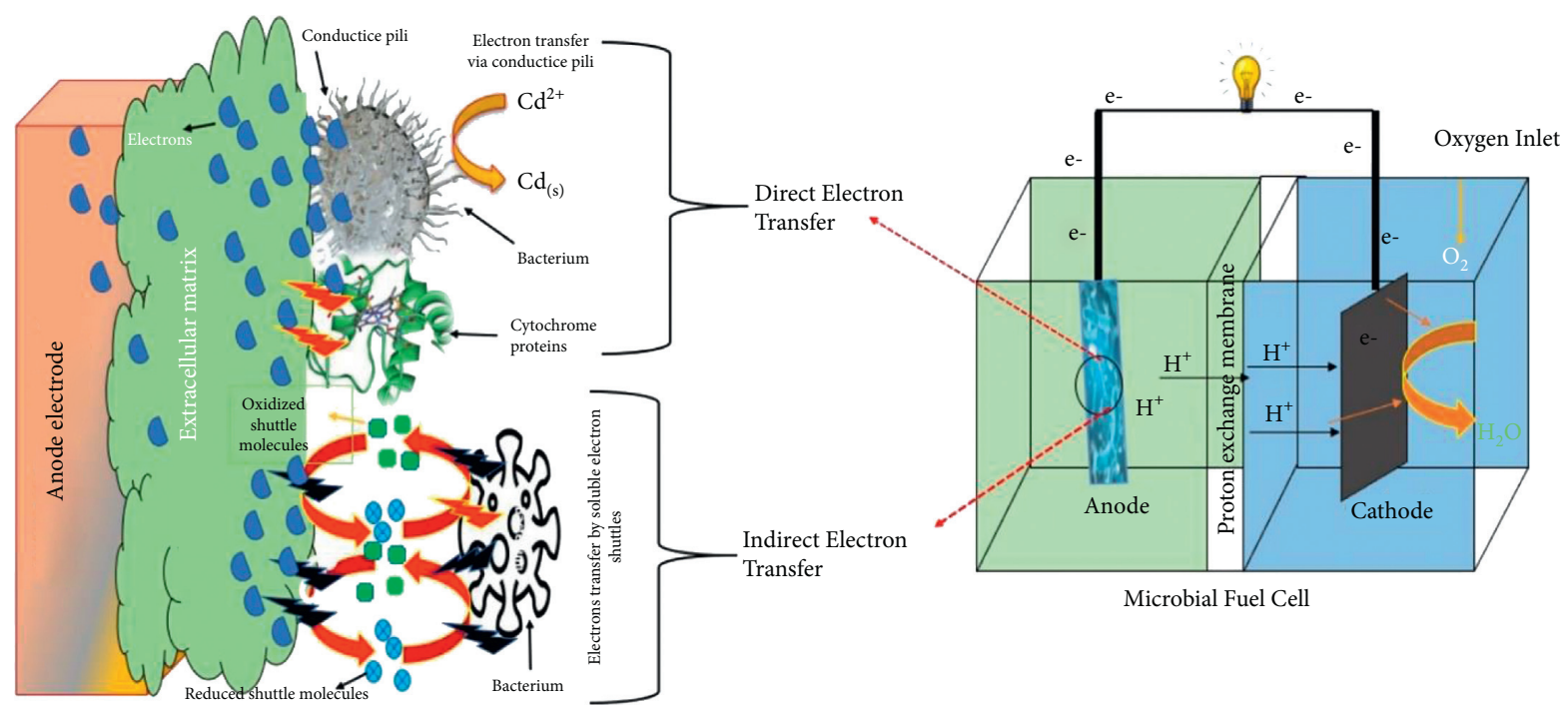

FIGURE 5: Electron transfer mechanism from a bacterial cell to the anode's surface (adapted from reference [20] with Elsevier's permission).

\section{Conclusion}

The present study highlighted the mango extract utilization in MFC as an organic substrate to remediate the toxic metal as well as generating energy. The present study delivered unique results such as $51 \mathrm{mV}$ voltage was recorded in 15 days operation of MFC, and maximum remediation efficiency of highly toxic metals was more than $80 \%$. The mango extract showed easy oxidation as compared to several other organic substrates. The CV results showed that oxidation was gradually increased, and a matured biofilm was developed without any hazardous effect on the surface of an anode. Similarly, SEM results also indicated that the anode surface is showing a dense and stable growth of bacterial species on the surface of an anode. High carbohydrate and bacterial compatible organic substrate can bring out the MFC from the instability of the organic substrate factor. Furthermore, the use of trash as a substrate, such as sugar cane waste, rice husk, carbohydrate-based waste, and so on, might be an alternate source in the future to enhance the shelf life of the organic substrate in MFC.

\section{Data Availability}

All data used to support their conclusions are available from the authors upon request.

\section{Consent}

Not applicable.

\section{Conflicts of Interest}

The authors declare that they have no conflicts of interest.

\section{Authors' Contributions}

Sundas Bahar Yaqoob and Showkat Ahmad Bhawani made equal contributions.

\section{References}

[1] B. E. Logan, B. Hamelers, R. Rozendal et al., "Microbial fuel cells: methodology and technology," Environmental Science \& Technology, vol. 40, no. 17, pp. 5181-5192, 2006.

[2] M. Rafatullah, Y. S. Chua, A. Ahmad, and K. Umar, "Recent advances in anodes for microbial fuel cells: an overview," Materials, vol. 13, no. 9, p. 2078, 2020.

[3] H. Ahmad, T. Parveen, A. Ahmad et al., "Recent advances in metal decorated nanomaterials and their various biological applications: a review," Frontiers in Chemistry, vol. 8, p. 341, 2020.

[4] A. A. Yaqoob, T. Parveen, K. Umar, and M. N. Mohamad Ibrahim, "Role of nanomaterials in the treatment of wastewater: a review," Water, vol. 12, no. 2, p. 495, 2020.

[5] A. Y. Asim, N. Mohamad, U. Khalid et al., "A glimpse into the microbial fuel cells for wastewater treatment with energy generation," Desalination and Water Treatment, vol. 214, pp. 379-389, 2021.

[6] M. H. Do, H. H. Ngo, W. S. Guo et al., "Challenges in the application of microbial fuel cells to wastewater treatment and energy production: a mini review," The Science of the Total Environment, vol. 639, pp. 910-920, 2018.

[7] L. Xu, Y. Zhao, L. Doherty, Y. Hu, and X. Hao, "The integrated processes for wastewater treatment based on the principle of microbial fuel cells: a review," Critical Reviews in Environmental Science and Technology, vol. 46, no. 1, pp. 60-91, 2016.

[8] A. S. Yaakop, K. Umar, and A. Ahmad, "Modified graphene oxide anode: a bioinspired waste material for bioremediation of $\mathrm{Pb} 2+$ with energy generation through microbial fuel cells," Chemical Engineering Journal, vol. 417, Article ID 128052, 2020.

[9] J. Liu, Y.-C. Yong, H. Song, and C. M. Li, "Activation enhancement of citric acid cycle to promote bioelectrocatalytic activity of arcA knockout Escherichia coli toward high-performance microbial fuel cell," ACS Catalysis, vol. 2, no. 8, pp. 1749-1752, 2012.

[10] N. N. M. Daud, A. Ahmad, A. A. Yaqoob, and M. N. M. Ibrahim, "Application of rotten rice as a substrate for bacterial species to generate energy and the removal of toxic metals from wastewater through microbial fuel cells," Environmental Science and Pollution Research, pp. 1-12, 2021. 
[11] F. S. Fadzli, M. Rashid, A. A. Yaqoob, and M. N. Mohamad Ibrahim, "Electricity generation and heavy metal remediation by utilizing yam (Dioscorea alata) waste in benthic microbial fuel cells (BMFCs)," Biochemical Engineering Journal, vol. 172, Article ID 108067, 2021.

[12] F. S. Fadzli, S. A. Bhawani, and R. E. Adam Mohammad, "Microbial fuel cell: recent developments in organic substrate use and bacterial electrode interaction," Journal of Chemistry, vol. 2021, Article ID 4570388, 16 pages, 2021.

[13] H. Li, Y. Tian, W. Zuo et al., "Electricity generation from food wastes and characteristics of organic matters in microbial fuel cell," Bioresource Technology, vol. 205, pp. 104-110, 2016.

[14] A. A. Yaqoob, M. N. Mohamad Ibrahim, and A. S. Yaakop, "Application of oil palm lignocellulosic derived material as an efficient anode to boost the toxic metal remediation trend and energy generation through microbial fuel cells," Journal of Cleaner Production, vol. 314, Article ID 128062, 2021.

[15] Q. Hou, C. Nie, H. Pei, W. Hu, L. Jiang, and Z. Yang, "The effect of algae species on the bioelectricity and biodiesel generation through open-air cathode microbial fuel cell with kitchen waste anaerobically digested effluent as substrate," Bioresource Technology, vol. 218, pp. 902-908, 2016.

[16] A. S. Yaakop and A. Ahmad, "Application of microbial fuel cells energized by oil palm trunk sap (OPTS) to remove the toxic metal from synthetic wastewater with generation of electricity," Applied Nanoscience, vol. 11, pp. 1949-1961, 2021.

[17] Z. Du, H. Li, and T. Gu, "A state of the art review on microbial fuel cells: a promising technology for wastewater treatment and bioenergy," Biotechnology Advances, vol. 25, no. 5, pp. 464-482, 2007.

[18] K.-J. Chae, M.-J. Choi, K.-Y. Kim et al., "Methanogenesis control by employing various environmental stress conditions in two-chambered microbial fuel cells," Bioresource Technology, vol. 101, no. 14, pp. 5350-5357, 2010.

[19] Y. Hong, D. F. Call, C. M. Werner, and B. E. Logan, "Adaptation to high current using low external resistances eliminates power overshoot in microbial fuel cells," Biosensors and Bioelectronics, vol. 28, no. 1, pp. 71-76, 2011.

[20] A. A. Yaqoob, A. Serrà, M. N. M. Ibrahim, and A. S. Yaakop, "Self-assembled oil palm biomass-derived modified graphene oxide anode: an efficient medium for energy transportation and bioremediating Cd (II) via microbial fuel cells," Arabian Journal of Chemistry, vol. 14, no. 5, Article ID 103121, 2021.

[21] M. Li, S. Zhou, and Y. Xu, "Performance of $\mathrm{Pb}$ (II) reduction on different cathodes of microbial electrolysis cell driven by Cr (VI)-reduced microbial fuel cell," Journal of Power Sources, vol. 418, pp. 1-10, 2019.

[22] C. Choi and Y. Cui, "Recovery of silver from wastewater coupled with power generation using a microbial fuel cell," Bioresource Technology, vol. 107, pp. 522-525, 2012.

[23] Z. Li, X. Zhang, and L. Lei, "Electricity production during the treatment of real electroplating wastewater containing Cr6+ using microbial fuel cell," Process Biochemistry, vol. 43, no. 12, pp. 1352-1358, 2008.

[24] C. Choi, N. Hu, and B. Lim, "Cadmium recovery by coupling double microbial fuel cells," Bioresource Technology, vol. 170, pp. 361-369, 2014.

[25] K. Umar, R. Adnan, and M. Rashid, "Graphene oxide-ZnO nanocomposite: an efficient visible light photocatalyst for degradation of rhodamine B," Applied Nanoscience, vol. 11, pp. 1291-1302, 2021.

[26] J. Jia, Y. Tang, B. Liu, D. Wu, N. Ren, and D. Xing, "Electricity generation from food wastes and microbial community structure in microbial fuel cells," Bioresource Technology, vol. 144, pp. 94-99, 2013.

[27] K. Umar, S. A. Bhawani, A. Khan et al., "Cellulose derived graphene/polyaniline nanocomposite anode for energy generation and bioremediation of toxic metals via benthic microbial fuel cells," Polymers, vol. 13, p. 135, 2021.

[28] A. Vijaya Bhaskar Reddy, V. Madhavi, A. Ahmad, and G. Madhavi, "Heavy metals removal using carbon based nanocomposites," in Environmental Remediation through Carbon Based Nano Composites, pp. 249-274, Springer, Berlin, Germany, 2021.

[29] K. P. Nevin, B.-C. Kim, R. H. Glaven et al., "Anode biofilm transcriptomics reveals outer surface components essential for high density current production in Geobacter sulfurreducens fuel cells," PLoS One, vol. 4, no. 5, Article ID e5628, 2009.

[30] A. Khatoon, S. H. Mohd Setapar, K. Umar, T. Parveen, A. Ahmad, and M. Rafatullah, "Outlook on the role of microbial fuel cells in remediation of environmental pollutants with electricity generation," Catalysts, vol. 10, p. 819, 2020.

[31] A. A. Yaqoob, M. N. M. Ibrahim, and S. Rodríguez-Couto, "Development and modification of materials to build costeffective anodes for microbial fuel cells (MFCs): an overview," Biochemical Engineering Journal, vol. 164, Article ID 107779, 2020.

[32] A. A. Yaqoob, M. N. M. Ibrahim, and C. Guerrero-Barajas, "Modern trend of anodes in microbial fuel cells (MFCs): an overview," Environmental Technology \& Innovation, vol. 23, Article ID 101579, 2021. 